\title{
Research on Teaching Methods and Ways of the Course Business Communication in Application-oriented Colleges

\author{
Yaxue PENG
}

\author{
Wuhan Business University, Wuhan, 430056, China \\ E-mail: 176781743@qq.com
}

Key words: Business Communication; curriculum teaching content design; curriculum teaching methods design; colleges and universities

\begin{abstract}
As one of the core course of business secretarial major, the course Business Communication Process and Product aims at cultivating students' interpersonal communication ability, teamwork communication awareness and teamwork spirit. For the comparatively highly application-oriented courses, such as Business Communication Process and Product, the traditional teaching method is more and more difficult to meet the requirements of personnel training. However, interactive teaching method can stimulate students' learning initiative and creativity through the mutual communication and mutual promotion between teachers and students. Various forms of interactive teaching methods can achieve good results in both teachers' teaching and students' learning. This paper analyzes this course due to its strong operability and practicability which is suitable for the application of projective teaching. The projective teaching design of this course will be discussed from three aspects, namely, teaching content, teaching methods and teaching process.
\end{abstract}

\section{Introduction}

Business Communication is a professional course combining theory with practice. And how to combine theory and practice in learning process is the keynote. [1]It is far less ideal by relying on cramming traditional teaching of theory and boring sermons. Because our students do not have social experience, it is hard and abstract for them to understand the theoretical knowledge of this course. In today's colleges and universities, the practical training section is mainly based on case analysis and discussion. [2] Because students have little direct contact with the enterprise and teachers have uneven selection and organization of using case analysis. Hence, the author boldly put classroom interaction in Business Communication Process and Product teaching to improve students' enthusiasm and interest. Additionally, let students learn knowledge, experience knowledge, and digest knowledge in interaction, then good teaching effect will be achieved.

\section{Features of this course}

\section{A. Teaching content}

Business Communication Process and Product is the basic course of management. It aims to help students to master the basic knowledge and basic principle of business communication, and be able to comprehensively apply it in practice. [3]In addition, it especially aims to help students to master and apply basic communication skills for being an excellent communicator. The course mainly includes two levels. The first level is for personal communication. The teaching content mainly consists of effective spoken expression, listening skills, nonverbal communication, speech, interview and telephone communication, business report writing and basic etiquette of business communication. The second level is for public communication. The teaching content mainly consists of group communication, meeting participation and intercultural communication.

\section{B. Teaching objectives}

The function of business communication involves nine aspects: introduction, listening, answering, questioning, discussion, negotiation, persuasion, rejection, compromise, marketing and 
business communication. [4] The setting of this course is to let students master business communication skills by absorbing basic knowledge of communication. Specifically, business communication can cultivate students' ability in the following aspects: first, written language and oral language ability; secondly, clear logical thinking ability; thirdly, accurate judgment ability; finally, good behavior and characteristic as well as the good business image.

\section{Projective teaching content design}

This course has unique framework and rich contents. The overall contents are around the study of business communication, involving principle level and strategy level. In the actual teaching of this course, teachers should try hard to figure out the communication principle, strategy and skills, design specified and practical project through constantly changing communication activities. Principles and rules, so as to reveal the art of communication activities, specifically, are several projects about this course. [5]Namely, business communication, self communication, interpersonal communication, business verbal communication, business written communication, business etiquette, business organizational communication, business customer communication, business negotiation, public relations crisis communication, e-commerce communication.

Knowledge requirements and skill requirements of each project are shown in Table 1.

Table 1: Knowledge requirements and skill requirements of each project

\begin{tabular}{|c|c|c|c|}
\hline order & Task of project & Requirements of knowledge & Requirements of skill \\
\hline 1 & $\begin{array}{l}\text { Know the business } \\
\text { communication }\end{array}$ & $\begin{array}{l}\text { - Connotation, type, key factors of } \\
\text { business communication }\end{array}$ & $\begin{array}{l}\text { - Grasp kinds of business } \\
\text { communicating media; } \\
\text { •recognize the principle and function } \\
\text { of business communication }\end{array}$ \\
\hline 2 & Self-communication & $\begin{array}{l}\text { - Self-recognition and analysis; } \\
\text { - self- communicating process; } \\
\text { - self-adjustment of emotion; } \\
\text { - self-communicating art }\end{array}$ & $\begin{array}{l}\text { - Grasp the method of } \\
\text { self-recognition and analysis; } \\
\text { - know the self- communicating } \\
\text { process; } \\
\text { - master the methods of } \\
\text { self-adjustment of emotion; } \\
\text { - know well several arts of } \\
\text { self-communication }\end{array}$ \\
\hline 3 & $\begin{array}{c}\text { Interpersonal } \\
\text { communication }\end{array}$ & $\begin{array}{l}\text { - Interpersonal relationship; } \\
\text { - art of interpersonal communication; } \\
\text { - Chinese special interpersonal } \\
\text { relationship }\end{array}$ & $\begin{array}{l}\text { - Know the key factor of influencing } \\
\text { interpersonal relationship: EQ; } \\
\text { - grasp the basic interpersonal } \\
\text { communicating skills ; } \\
\text { - understand the characteristics of } \\
\text { Chinese traditional interpersonal } \\
\text { relationships }\end{array}$ \\
\hline 4 & $\begin{array}{c}\text { Business } \\
\text { communication }\end{array}$ & $\begin{array}{l}\text { - Business communication; } \\
\text { - non-verbal communication in business } \\
\text { activities }\end{array}$ & $\begin{array}{l}\text { - Grasp principles of business } \\
\text { communication; } \\
\text { - grasp methods of statement, } \\
\text { questioning and listening; } \\
\text { - Correctly use several non-verbal } \\
\text { language }\end{array}$ \\
\hline 5 & $\begin{array}{l}\text { Business written } \\
\text { communication }\end{array}$ & $\begin{array}{l}\text { - Business correspondence; } \\
\text { - business invitation; } \\
\text { - business report }\end{array}$ & $\begin{array}{l}\text { - Grasp the common writing of } \\
\text { business correspondence, } \\
\text { invitation and report }\end{array}$ \\
\hline 6 & Business etiquette & $\begin{array}{l}\text { - The connotation and function of } \\
\text { business etiquette; } \\
\text { - basic business etiquette; } \\
\text { - etiquette in social activities }\end{array}$ & $\begin{array}{l}\text { - Grasp basic business } \\
\text { etiquette(appearance); } \\
\text { - grasp basic etiquette in social } \\
\text { activities(introduction, telephone, } \\
\text { eating, sitting, talking, etc) }\end{array}$ \\
\hline 7 & $\begin{array}{c}\text { Business } \\
\text { organization } \\
\text { communication }\end{array}$ & $\begin{array}{l}\text { - Team communication; } \\
\text { - communicating with higher-up; } \\
\text { - communicating with subordinate }\end{array}$ & $\begin{array}{l}\text { - Know the features and spirit of } \\
\text { team; } \\
\text { grasp effective team } \\
\text { communicating skills; }\end{array}$ \\
\hline
\end{tabular}




\begin{tabular}{|c|c|c|c|}
\hline & & $\begin{array}{l}\text { workers; } \\
\text { - communicating with media; } \\
\text { - communicating with government and } \\
\text { cross-cultural communication }\end{array}$ & $\begin{array}{l}\text { - grasp communicating skills with } \\
\text { higher-up or subordinate workers; } \\
\text { - grasp the strategies with media or } \\
\text { company or government; } \\
\text { - grasp effective communicating } \\
\text { methods with cross-cultural team; } \\
\text { - grasp the cross-cultural } \\
\text { communicating strategies }\end{array}$ \\
\hline 8 & $\begin{array}{l}\text { Communication } \\
\text { between business } \\
\text { costumers }\end{array}$ & $\begin{array}{l}\text { - Types of costumers; } \\
\text { - communicating strategies between } \\
\text { costumers; } \\
\text { - Customer complaint handling skills }\end{array}$ & $\begin{array}{l}\text { - Understand customer service; } \\
\text { - grasp kinds of communicating } \\
\text { - strategies with costumers; } \\
\text { - grasp kinds of customer complaint } \\
\text { handling skills }\end{array}$ \\
\hline 9 & Business negotiation & $\begin{array}{l}\text { - Definition and principle of business } \\
\text { negotiation; } \\
\text { - strategies, procedure of business } \\
\text { negotiation; } \\
\text { - verbal and non-verbal business } \\
\text { communicating art }\end{array}$ & $\begin{array}{l}\text { - Know the principle of business } \\
\text { negotiation; } \\
\text { - grasp the strategies of each period } \\
\text { in business negotiation; } \\
\text { - grasp verbal and non-verbal } \\
\text { business communicating art }\end{array}$ \\
\hline 10 & $\begin{array}{c}\text { Public relations crisis } \\
\text { communication }\end{array}$ & $\begin{array}{l}\text { - Definition of public relations; } \\
\text { - definition, type, features, reasons of } \\
\text { public crisis; } \\
\text { - dealing strategies of each period in } \\
\text { public relations crisis; } \\
\text { - management of dealing with public } \\
\text { relations crisis }\end{array}$ & $\begin{array}{l}\text { - Grasp the features and reasons of } \\
\text { public relations crisis; } \\
\text { - grasp dealing strategies of each } \\
\text { period in public relations crisis; } \\
\text { - grasp methods of dealing with the } \\
\text { spread of public relations crisis }\end{array}$ \\
\hline 11 & $\begin{array}{c}\text { E-commerce } \\
\text { communication }\end{array}$ & $\begin{array}{l}\text { - Definition, classification, mode and } \\
\text { common trade process of e-commerce; } \\
\text { - features and requirements of } \\
\text { e-commerce communication }\end{array}$ & $\begin{array}{l}\text { - Grasp several types and modes of } \\
\text { e-commerce; } \\
\text { - grasp common trade process of } \\
\text { e-commerce communication; } \\
\text { - grasp different e-commerce } \\
\text { communicating methods }\end{array}$ \\
\hline
\end{tabular}

\section{Projective teaching methods design}

According to the laws of this course, we should change the traditional teaching methods which are teacher centered, theoretical knowledge centered and classroom teaching centered. Instead, situational teaching, game exercise, team training, case teaching, role play and other new teaching methods should be applied. In this way, students can be motivated into role exchange, group collaboration and teamwork.

a. Situational simulation method

Situational simulation teaching refers to the simulation or virtual representation of events and its development or environment. Students can improve their ability in a short period of time through understanding the teaching contents in a cognitive approach. Situational teaching pays attention to the students' real experience of communicating in real situation or their mental experience by imitating real communication. It is a kind of strong interactive teaching form, while business communication aims to develop students' communicating ability, train students' communication skills, strengthen students' emotional experience and let them observe, reflect, explore and put into practice. Teachers can set up a business situation in advance so that students naturally receive knowledge and training.

\section{b. Case analysis method}

Case teaching method refers that according to the teaching contents and teaching objectives, teachers cultivate students' comprehensive quality through creating cases, organizing students to research, analyze, express, etc. On the one hand, this teaching method can deepen students' understanding of abstract knowledge and enhance students' recognition ability. On the other hand, it enhances students' ability to analyze and solve problem by encouraging students themselves to find 
solutions when meeting some difficult case analysis.

C. Collaborative learning method

Cooperative teaching method is a reasonable combination of various teaching factors. Teaching effect and interaction between students are more reflected through good collaboration. In teaching process, considering students' actual situation and based on teaching tasks, teachers divide students into different study groups to guide them into group cooperation and practice. Group members would have great differences in intelligence, personality, academic achievement, family and social background. They can have fully interactive and complementary collaboration. This method provides students with the opportunity to cooperate with each other, so that students can actively and consciously cultivate spirit of cooperation, exercise cooperating ability and share learning resources.

d. Task-driven method

Task-driven teaching method refers that in the teaching process, teachers use specific tasks as link, cleverly attach teaching content into each task. Then let students put forward questions answer their own questions, with the help of their own thinking and the coaching of teachers. For example, when teachers teach the part "persuasiveness in communication", teachers could assign the task at first. Then, students form groups by themselves, each group will have the same task assigned by teachers. In their group discussion, teachers encourage students to persuade each other through communication and finally sum up the key points of persuasiveness. After that, students make preparation and design the communicating process. After giving enough time to students, teacher picks two groups to present their persuading process and gives relevant encouragement in order that students can feel the sense of self-achievement, self-value and happiness. After students' presentations, teacher could ask for other groups' opinion, then teacher give feedback to conclude the key points of persuasiveness. The feature of task-driven teaching method is that student will have enough learning autonomy when they are driven to accomplish tasks. In this way,students will be able to master theoretical knowledge of business communication and then cultivate their own practical skills and innovative consciousness. In a word, this method can maximize the subjective initiative of students and greatly improve students' learning skills and language ability.

\section{Conclusion}

To sum up, it is necessary to use a variety of teaching methods in the teaching of this course. The course Business Communication Process and Product aims at treating students as the center as well as the major role in class. The whole teaching process would combine teaching, learning and training together. The teaching methods which highlight training would integrate theoretical requirements and basic knowledge of this course into the skill training. Teachers must be very familiar with the curriculum theory and teaching content, and have strong responsibility as well as the investment of time and energy in order to strengthen the control and management of teaching. At the same time, in the skill training of business communication, teachers need to promptly summarize the whole teaching process to strengthen the training effect. In the end, the evaluation of students' scores will be based on the assessment of students' theoretical knowledge and their communication training effects. We should constantly explore the interactive teaching method in the future teaching practice, and get continuous improvement.

\section{Acknowledgement}

In this paper, the research was sponsored by Wuhan Business University, and the Project Name is Excellent Course Business Communication.

\section{References}

[1] Dipankar Ghosh,Terry L. Crain. Ethical standards, attitudes toward risk, and intentional noncompliance: An experimental investigation[J]. Journal of Business Ethics . 1995 (5) 
[2] Bachman L.Language assessment:Opportunities and challenges. the meeting of the A-merican Association of Applied Linguistics . 2007

[3] Stephen R. Hawk. The effects of computerized performance monitoring: An ethical perspective[J]. Journal of Business Ethics. 1994 (12)

[4] Jeffrey R. Cohen,Laurie W. Pant,David J. Sharp. Cultural and socioeconomic constraints on international codes of ethics: Lessons from accounting[J]. Journal of Business Ethics . 1992 (9)

[5] Leung, K,Wang, Z. M,\& Smith, P. B.Job attitudes and organizational justice in joint venture hotels in China: the role of expatriate managers. International Journal of Human Resource Management. 2001 